\title{
Measurement of glucose concentration based on femtosecond two-color pulse interferometry
}

\author{
○学 堀 泰明（阪大院基工） \\ 安井 武史（阪大院基工） \\ 正 荒木 勉（阪大院基工） \\ Yasuaki HORI, Takeshi YASUI, and Tsutomu ARAKI \\ Graduate school of Engineering Science , Osaka University
}

Key Words : blood sugar, glucose concentration, femtosecond, dispersion of refractive index, optical multiple scattering

1.はじめに

現在，糖尿病の検査には血液を採取して血糖値（血 液中のグルコース濃度）を測定する方法が一般に用い られている。また糖尿病と診断されると一日に数回の 採血が必要となる。この採血に伴う精神的苦痛は患者 にとって大きな負担となっており，衛生的かつ負担の 少ない非観血型血糖測定法の開発が求められている.

光学的手法による血糖值測定の研究は，1970 年代 から報告されており，その主なものに近赤外吸収分光 法 ${ }^{1}$ と旋光度測定法 ${ }^{2}$ がある。近赤外吸収分光法は, グルコースが近赤外域にもつ固有の吸収バンドにお いて, 吸光度が濃度に依存して変化することを利用し ている.旋光度測定法は,グルコース溶液に直線偏光 を入射したときに偏光面が回転する現象（旋光）を利 用し,この回転角 (旋光度) が濃度に比例することから 濃度測定を行っている。しかし，いずれの手法も臨床 血糖測定に必要な測定精度を満たしているとは言い がたい.その一つの原因が血液中に存在する血球粒子 等による光多重散乱の影響である。例えば，近赤外吸 収分光法においては，吸収と散乱とによる透過光強度 の減衰を識別することが困難であり，旋光度測定法に おいては, 偏光面の乱れが散乱によって生じ, その結 果，測定精度が低下する。

多重散乱の影響を効果的に除去する方法の一つと して，光の可干渉性(コヒーレンス)を利用したコヒー レンスゲートがある。コヒーレンスを持った光を散乱 体に入射すると多重散乱光によりコヒーレンスを失う 一方で，散乱の影響を受けずに透過する直進光はコヒ ーレンスを保持する. 従って，参照光と透過光を干渉 させることによって直進光のみを取り出すことができ る。特に超短パルスレーザーを光源として用いた場合， パルスの持つ高いピークパワーと低コヒーレンス性に より， $\mathrm{SN}$ 比の向上, 測定精度の向上を得ることがで きる。

このような考えに基づき，本研究ではフェムト秒 2 色パルス干涉法(FTPI) ${ }^{3}$ をダルコース濃度測定に応用 し, 測定精度及び多重散乱光除去効果の評価を行った。

\section{2.測定原理}

一般に，物質の屈折率は透過する光の波長により異 なる(屈折率分散). 例えば, Fig.1に示す様に波長の異 なる赤色と青色のパルス光をグルコースサンプルに同 時入射すると，通過時間に差が生じる。この差(時間遅
延)はグルコース濃度に比例して大きくなるため,この 時間遅延を測定することによりグルコース濃度を求め ることが出来る。この時間遅延は FTPIで測定する。

\section{3.測定装置}

FTPIの光学系をFig.2 に示す．光源にはモードロッ ク・チタンサファイアレーザー(中心波長 $800 \mathrm{~nm}$, パ ルス幅 $80 \mathrm{fs}$, 出力 $200 \mathrm{~mW}$, 繰り返し周波数 $87 \mathrm{MHz}$ ) を使用している. 波長 $400 \mathrm{~nm}$ の青色パルス光には, レ 一ザーから射出された波長 $800 \mathrm{~nm}$ の赤色パルス光を 第 2 高調波発生結晶( SHG 結晶) に入射すると発生す る第 2 高調波発生光を用いる. SHG 結晶直後には 2 色 パルス光(赤色・青色パルス光)は時間的・空間的に重
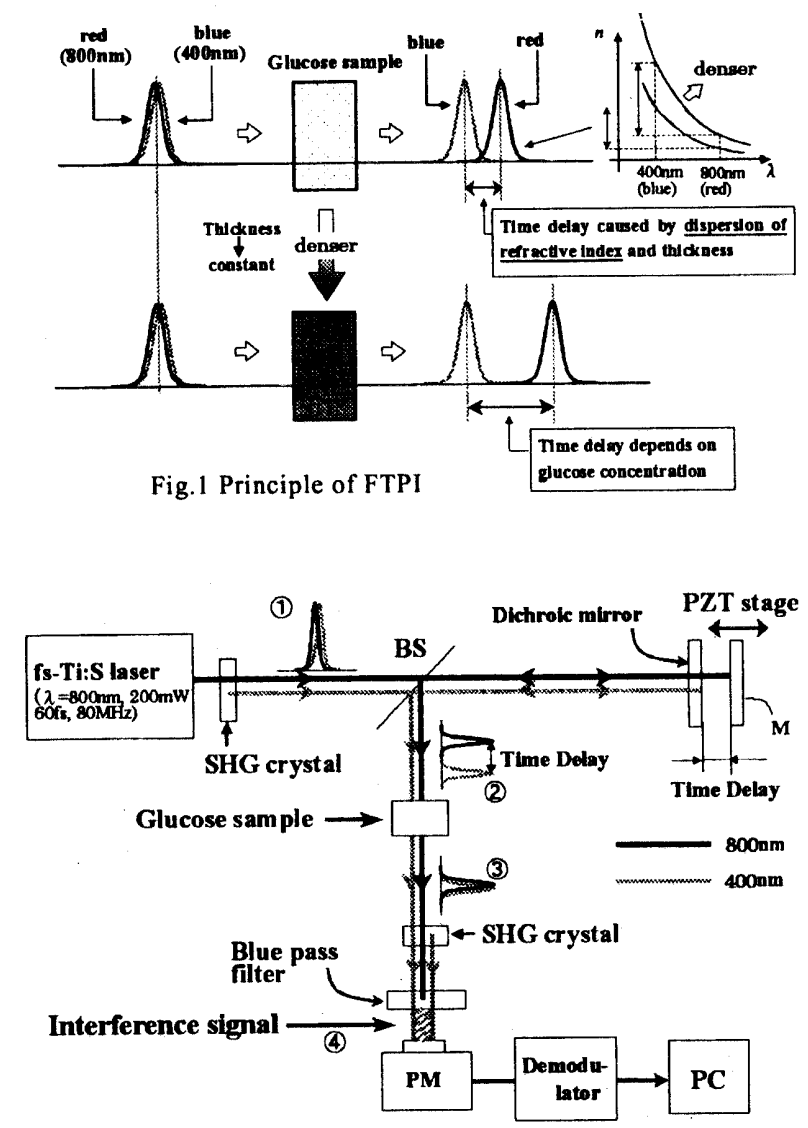

Fig.2 Experimental setup of FTPI 
なっており(1)，ダイクロイックミラー(赤色透過, 青 色反射)とピエゾステージ(PZT stage)に取り付けたミ ラー $(\mathrm{M})$ によって，2 色パルス間に任意の時間遅延を 生じさせることができる(2)，サンプル透過した 2 色 パルス光(3))のうち, 赤色パルス光は再び SHG 結晶で 青色パルス光に変換され, 青色フィルタ (Blue pass filter)によって残りの赤色パルス光をカットする。グ ルコース溶液の屈折率分散による時間遅延とピエゾス テージによる時間遅延が一致した場合のみ，青色パル ス光同士のパルス干涉信号が生成される，光電子增倍 管 (PMT)によって検出されたパルス干涉信号 (Fig.3 (a)) は, 復調器 (Demodulator)により包絡線が抜 き取られる(Fig.3(b))。グルコース溶液の濃度変化は， 干涉信号ピークの時間シフトを引き起こすので，この 時間シフトを測定することによりグルコース濃度を求 めることが出来る。

FTPI の光学系は 2 色パルスの準共通光路干涉計の 構成をとっており，従来の干涉計測で問題とされた外 乱(空気摇らぎ, 音波, 振動の影響) を相殺して, 安定 な計測を行うことが出来る。また，パルス干涉を用い たコヒーレンスゲートにより, 多重散乱光の除去も可 能である。

\section{3. 実験結果}

3.1 グルコース濃度測定

グルコース濃度測定では, 臨床血糖值濃度 (100 $200 \mathrm{mg} / \mathrm{dl}$ ) を考慮して，0，50，100，150，200，250， $300 \mathrm{mg} / \mathrm{dl}$ のグルコース溶液をサンプルとして用いた。 セル光路長は $10 \mathrm{~mm}$ である. 各濃度に扔けるパルス干 涉の包絡線の時間遅延をそれぞれ 10 回ずつ測定した。 その結果がFig.4である. 測定の確度 (accuracy)を平均 值の近似直線からのばらつきの標準偏差と定義すると, $4.37 \mathrm{mg} / \mathrm{dl}$ になる。一方, 精度 (precision) は各濃度 10 回測定のばらつきから求められ， $71.4 \mathrm{mg} / \mathrm{dl}$ と大きな 值となっている.

3.2 散乱光除去

パルス干涉による多重散乱光除去の評価には，イン トラリピッド溶液を散乱体モデルとして使用した。サ ンプル光路長は $1 \mathrm{~mm}$ である。一般に生体組織の散乱 係数は，1\%イントラリピッド濃度に相当する.今回の 実験では，0.1〜1.0\%濃度のイントラリピッド溶液を 使用し，各濃度における干涉信号の包絡線を検出した。 そのうち $0.1 \sim 0.4 \%$ 濃度の結果を Fig. 5 に示す。この 結果, 約 $0.3 \%$ イントラリピッド濃度に相当する生体組 織に拈いて，非散乱光をとりだすことが可能であるこ とが分かった。

\section{4.まとめ}

FTPI によるグルコース濃度測定精度を行った結果， 確度が $4.37 \mathrm{mg} / \mathrm{dl}$, 精度が $71.4 \mathrm{mg} / \mathrm{dl}$ という結果となっ た。また,散乱体を用いた多重散乱光除去の評価では, 生体組織と同程度の散乱係数では，直進光が検出でき なかった

グルコース濃度測定精度の評価に関して, 各濃度の ばらつきが大きくなった主な原因は，包絡線を拔き出 す復調器回路及び解析方法等にあると考えている。こ れらの問題を解決して精度の向上を目指す。また，多 重散乱光除去に関しては, 今後は検出感度をさらに向
上させる必要があり，ロックインアンプ等を用いて計 測を高感度化する必要がある。

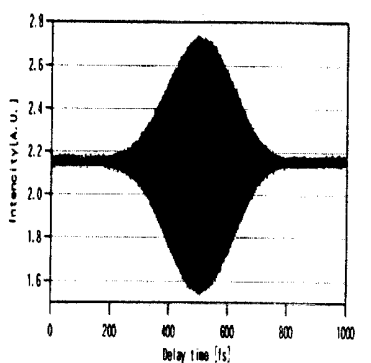

(a)

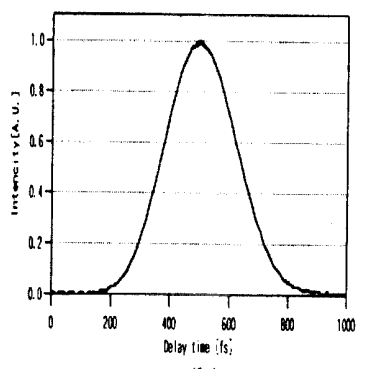

(b)
Fig.3 Interference signal. (a) Fringe signal and (b) envelop signal by demodulation.

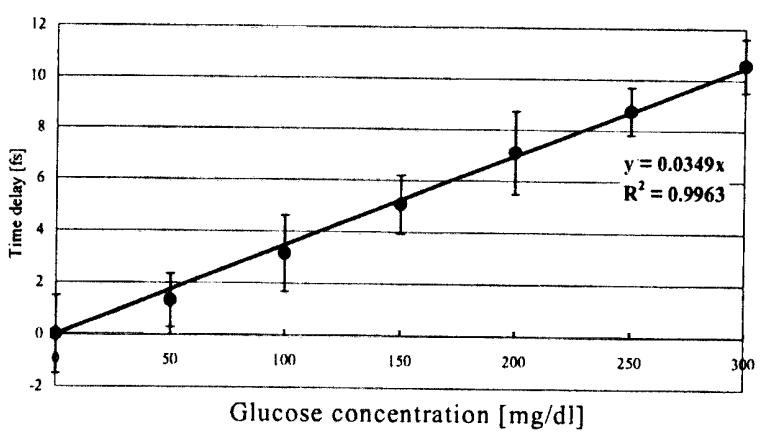

Fig. 4 Result of glucose concentration measurement.

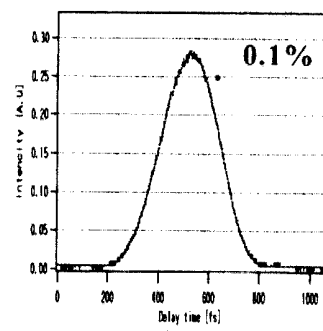

(a)

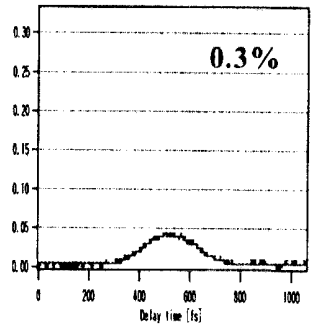

(c)

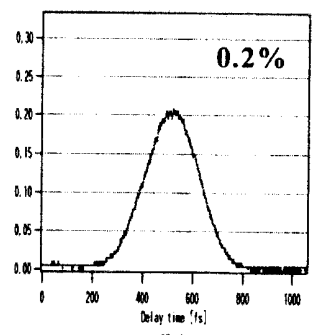

(b)

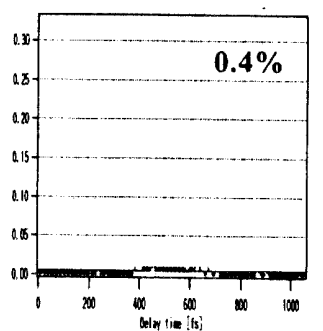

(d)
Fig.5 Interference signal under optical scattering media.

\section{謝辞}

本研究は, 文部科学省科学研究費補助金・若手研究 (B) 13750045 により援助を受けた。

\section{参考文献}

1) H.Zeller et al, Int. J. Artif. Organs., 12, 129 (1989)

2) C.Chou et al, Jpn. J. Appl. Phys., 36, 356 (1997)

3) K.Minoshima et al, Opt.Comm., 138, 6 (1997) 